GEFAD / GUJGEF41(2): 601-630(2021)

\title{
Fen Bilimleri Dersi “İnsan ve Çevre" Ünitesi Akademik Başarı Testi Geliştirme: Güvenirlik ve Geçerlik Çalışması *
}

\author{
Science Course "Human And Environment" Unit \\ Academic Achievement Test Development: Reliability And \\ Validity Study
}

\author{
Özge ÇİÇEK ŞENTÜRK ${ }^{1}$, Mahmut SELVi ${ }^{2}$ \\ ${ }^{1}$ Kilis 7 Aralı Üniversitesi, Muallim Rlfat Eğitim Fakültesi, Matematik ve Fen Bilimleri \\ Ĕ̌itimi Bölümü, Fen Bilgisi Ĕ̈itimi Anabilim Dalı, \\ ozgecicek@kilis.edu.tr \\ ${ }^{2}$ Gazi Üniversitesi, Gazi Eğitim Fakültesi, Matematik ve Fen Bilimleri Eğitimi Bölümü, \\ Fen Bilgisi Eğitimi Anabilim Dal,, \\ mselvi@gazi.edu.tr
}

\section{$\ddot{O} Z$}

Bu araştırmanın amacı, 5. sınıf fen bilimleri dersindeki "İnsan ve Çevre" ünitesine ilişkin ölçme ve değerlendirme aracı olarak kullanılabilecek geçerliği ve güvenirliği test edilmiş bir akademik başarı testi gelişstirmek ve tüm aşamalarını detaylı olarak sunmaktır. Ilgili üniteye ait sekiz adet kazanım için belirtke tablosu hazırlanarak oluşturulan kırk soruluk soru havuzu için uzman görüşüne başvurulmuştur. Araştırma örneklemi oluşturulurken ölçüt örnekleme kullanılmıştır. Ölçüt olarak ilgili üniteyi geçen yıllarda öğrenmiş olma ölçütü baz alındı̆̆ından araştırmanın örneklemi 6., 7. ve 8. sinıf ortaokul ögrencileridir. Araştırmadan elde edilen veriler için testin ortalama madde güçlügü, madde ayırt ediciliği ve madde- toplam korelasyonu ile KR-20 güvenirlik katsayısı hesaplanmıştır. Madde analizleri sonucunda testin 27 maddeden oluştuğu görülmüşürr. Testin son hali için ortalama madde güçlüğ̈̈ 0,62; ortalama madde ayırt ediciliği 0,47; KR-20 güvenirlik katsayısı 0,82 olarak hesaplanmıştır. Geliştirilen testin ögrrencilerin ünite

\footnotetext{
*Alıntılama: Çiçek Şentürk, Ö. ve Selvi, M. (2021). Fen bilimleri dersi "insan ve çevre" ünitesi akademik başarı testi geliştirme: güvenirlik ve geçerlik çalışması. Gazi Üniversitesi Gazi Ĕgitim Fakültesi Dergisi, 41(2), 601-630.

** Bu çalışma Prof. Dr. Mahmut SELVİnin danışmanlığında yürütülen Özge ÇIÇEK ŞENTÜRK'ün doktora tez çalışmasının bir kısmından türetilmiş ve VI. International Eurasian Educational Research Congress'te bir kısmı sunulmuştur.
} 
kazanımlarına ulaşma düzeylerini tespit etmek için öğretmenlere yararlı olacă̆ düşünülmektedir.

Anahtar Sözcükler: Çevre başarı testi, Ortaokul öğrencileri, Güvenirlik, Geçerlik.

\section{ABSTRACT}

This study aims to develop an achievement test whose validity and reliability have been tested that can be used for the 5th grade "Human and Environment" unit and to present all its stages in detail. Expert opinion was consulted for the question pool of 40 questions created by preparing a table of specifications for eight learning outcomes. While creating the research sample, criterion sampling was used. As a criterion, having learned the "Human and Environment" unit in science course in previous years was taken into account. Therefore, the sample is secondary school $6^{\text {th }}$, $7^{\text {th }}$, and $8^{\text {th }}$ grade students. The KR-20 value of the test is 0.82; mean item difficulty index value 0.62; mean item discrimination index was calculated as 0.47. It is thought that the test will be useful for teachers in determining the level of achieving the unit gains of their students.

Keywords:Environment achievement test, Middle school students, Reliability, Validity 


\section{GíRiş}

Öğrencilerin çevre sorunlarına karşı duyarlı olmaları, bu sorunları çözebilmek için sorumluluk almaları, doğayı sevmeleri ve korumaları, çevre bilinci geliştirmeleri yıllardır pek çok dersin öğretim programının hedefleri arasındadır. Buna rağmen çevreye karşı duyarlılık noktasında beklenilen düzeye ulaşılamamıştır (Armağan, 2006). Doğal çevreyi tanıyan, temas halinde olan ve çevrenin bir parçası olmayı yaşam tarzı haline getiren bireylerin yetiştirilmesine katkı sağlayan kazanım ve ünitelere 2018 Fen Bilimleri Dersi Öğretim Programı'nda da yer verilmiştir. Bu üniteler ile öğrencilerin yaşam için gerekli kaynakları dikkatli kullanmaları, çevreyi sevmeleri, sorumluluk almaları, çevre sorunlarına ilişkin sebep ve sonuçları sorgulamaları, nesli tükenmiş ve tükenme tehlikesi altında olan bitki ve hayvan türlerini korumaları, doğal afetler hakkında bilgi sahibi olmaları hedeflenmiştir.

2018 Fen Bilimleri Dersi Öğretim Programı'nda ortaokul 5. sınıfta bu hedeflere ulaşmayı sağlayan konu ve kavramlar "İnsan ve Çevre" ünitesinde yer almaktadır. Bu ünitede yer alan sekiz adet kazanım ile öğrencilerin çevre hakkında temel bilgiler kazanması, insan-çevre arasındaki ilişkiyi anlamaları, doğadaki ve yakın çevresindeki olaylara karşı ilgi duymaları, nesli tükenmiş canlıları bilmeleri ve şu an tükenme tehlikesi altında olan canlı türlerini korumaları, çevre sorunlarının sebeplerini ve sonuçlarını sorgulayabilmeleri, insan etkisiyle oluşan çevre problemlerine karşı hassasiyet geliştirmeleri, yıkıcı doğa olaylarını ve korunma yollarını bilmeleri amaçlanmıştır. $\mathrm{Bu}$ kazanımlara ulaşırken öğrenme-öğretme sürecinde öğrencilerin keşfetmesi, sorgulaması yani sürece dâhil olması da gözetilmiştir.

Yukarıda bahsedilen öğrencilerin ulaşması beklenen kazanımlar, içerik bilgisi ve öğrenme-öğretme durumları aslında bir dersin öğretim programının temel unsurlarıdır. $\mathrm{Bu}$ unsurlar kapsamında yer alan sınama (ölçme ve değerlendirme) durumları da öğrenciye geri bildirim verilmesi açısından oldukça önemlidir. Eğitim sisteminin herhangi bir seviyesinde bir konu velveya dersi öğretmenin amaçlarını gerçekleştirmek 
için eğitim süreçlerinin ve ürünlerinin kalitesinin izlenmesine ve sürdürülmesine ihtiyaç vardır. Okullarda öğrenim ve öğretimin kalite ve standartların izlemenin önemli bir yolu, öğrencilerin öğrenme çıktılarının değerlendirilmesidir. Öğrencilerin öğrenmeden önce hazırbulunuşluk düzeylerinin, öğrenme sürecinde derse yönelik tutumlarının, öğrenmenin sonunda başarı düzeylerinin belirlenmesinde kullanılan çeşitli ölçme ve değerlendirme araçları öğretim sürecinin bir parçasıdır (Kubanç, 2019).

Öğrencilerin performansını ölçmek için açık uçlu sorular, doğru-yanlış soruları, çoktan seçmeli testler gibi çeşitli ölçme araçları kullanılır (Karip, 2012). Öğrencilerin öğrenme seviyelerinin tespitinde kullanılan ölçme araçlarından biri olan çoktan seçmeli testler, nesnel puanlama, farklı sınav çeşitlerine göre daha fazla kapsam geçerliği sağlama, puanlama kolaylığı, puanlama güvenirliğinin daha fazla olması, kalabalık gruplarda uygulama rahatlığı sağlaması bakımından tercih edilmektedir (Çardak \& Selvi, 2018).

Öğrencilerin bir konuya ilişkin akademik başarı seviyelerinin ölçülmek istendiği durumlarda çoktan seçmeli başarı testleri geliştirilmekte ve araştırmalarda kullanılmaktadır (Ahmad, Sultana \& Jamil, 2020; Akbulut \& Çepni, 2013; Kargın \& Gül, 2021; Nacaroğlu, Bektaş \& Kızkapan, 2020; Üçüncü \& Sakız, 2020). Başarı testleri öğrencilerin öğretim programındaki konu ve ünitelerin kazanımlarına ulaşma derecesini belirlemeye dair bilgi sağlar ve ihtiyaç duyulan eğitimsel durumların ortaya çıkarılmasında kullanılır. Çoktan seçmeli başarı testleri farklı bilişsel alan seviyelerine göre soru hazırlama, objektif puanlama yapma, grupları karşılaştırmaya imkân tanıma, tekrar kullanılabilir olma özellikleri sayesinde oldukça kullanışlı bir ölçme aracıdır (Özaşkın Arslan \& Karamustafaoğlu, 2019).

Başarılı bir eğitim sürecinin temel unsurlarından biri, başarılı bir değerlendirme sürecidir. Ancak okullarda kullanılan ölçme araçlarının çoğu öğretmenler tarafından hazırlanmaktadır. Bu nedenle, öğrencilerin başarı seviyelerini tespit etmek için geçerli ve güvenilir başarı testlerine ihtiyaç vardır (Fidan, 2013). Bu araştırma kapsamında, 5. sınıf "İnsan ve Çevre" ünitesine yönelik ölçme ve değerlendirme aracı olarak kullanılabilecek geçerliği ve güvenirliği test edilmiş bir akademik başarı testi geliştirmek ve tüm aşamalarını detaylı olarak sunmak amaçlanmıştı. Öğretmenlerin 
çoğunun sınıflarında uyguladıkları akademik başarı testleri için geçerlik ve güvenirlik çalışmalarını yapmamaları öğrencilerin performansına ilişkin yanlış değerlendirme ve kararlara neden olabilmektedir (Opara \& Magnus-Arewa, 2017). Bu sebeple geçerlik ve güvenirlik çalışması yapılmış olan bu testin, 2018 Fen Bilimleri Dersi Öğretim Programı'nda altıncı ünite olan "İnsan ve Çevre" ünitesi işlendikten sonra öğrencilerin ünite kazanımlarına ulaşma düzeylerini tespit etmek, ünite sonunda öğrencilere eksikliklerini bildirmek veya ödevlendirme olarak kullanmak için öğretmenler açısından işlevsel olacağı düşünülmektedir. Başarı testinin geliştirme basamaklarının tüm detayları ile açıklanmış olması farklı üniteler için başarı testi geliştirmeyi planlayan araştırmacılara da yardımcı olacaktır. Çalışmanın bu yönleriyle alanyazına katkı sağlaması ve ileride yapılacak çalışmalara ışık tutması beklenmektedir.

Araştırmanın amacı kapsamında araştırma soruları şu şekildedir:

1) 5. sınıf Fen Bilimleri dersi "İnsan ve Çevre" ünitesine ilişkin geliştirilen Çevre Başarı Testi'nin ortalama madde güçlük indeksi nedir?

2) 5. sınıf Fen Bilimleri dersi "İnsan ve Çevre" ünitesine ilişkin geliştirilen Çevre Başarı Testi'nin ortalama madde ayırt edicilik indeksi nedir?

3) 5. sınıf Fen Bilimleri dersi “İnsan ve Çevre” ünitesine ilişsin geliştirilen Çevre Başarı Testi'nin güvenirlik katsayısı nedir?

\section{YÖNTEM}

$\mathrm{Bu}$ bölümde çalışmanın yöntemi, evren ve örneklem, veri toplama aracı, verilerin analizi başlıkları altında detaylı olarak açıklanmıştır.

\section{Evren ve Örneklem}

$\mathrm{Bu}$ çalışmanın evreni, 2018-2019 eğitim-öğretim yılı bahar dönemi içerisinde Türkiye'nin güneydoğusunda bir ilde öğrenim görmekte olan 6., 7. ve 8. sinıf öğrencileridir. Ölçüt örneklemeden yararlanılarak bu çalışmanın örneklemi belirlenmiştir. Ölçüt örnekleme önceden belirlenen bazı ölçütlerilkriterleri sağlayan 
durumları çalışmada kullanılan amaçlı örnekleme yöntemlerinden biridir (Patton, 2014). Örnekleme katılım ölçütü olarak "İnsan ve Çevre” ünitesini önceki yıllarda fen bilimleri dersinde işlemiş olma koşulu esas alınmıştır. Bu sebeple araştırmanın örneklemi 6., 7. ve 8. sınıf ortaokul öğrencileridir. Testin güvenirliğini arttırmak için testte yer alan madde sayısının en az beş katı kadar öğrenci ile uygulama yapılması gerektiği göz önünde bulundurulmuştur (Tavşancıl, 2010). Çalışma 273 öğrenci ile gerçekleştirilmiş ve bu öğrencilere ait demografik özelliklere Tablo 1'de yer verilmiştir.

Tablo 1. Örnekleme İlişkin Bilgiler

\begin{tabular}{cc}
\hline Sınıf Düzeyi & N \\
\hline 6.sinıf & 95 \\
7. sinıf & 81 \\
8.sinıf & 97 \\
Toplam & 273 \\
\hline Cinsiyet & $\mathbf{N}$ \\
\hline Kiz & 113 \\
Erkek & 160 \\
Toplam & 273 \\
\hline
\end{tabular}

\section{Veri Toplama Aracı}

Bu çalışma kapsamında, araştırmacılar tarafından hazırlanan, 5. sınıf "İnsan ve Çevre" ünitesine ilişkin akademik başarı testinin kırk maddeden oluşan taslak hali veri toplama aracı olarak kullanılmıştır. Bu teste nihai hali verilene kadar gerçekleştirilen geçerlik ve güvenirlik çalışmaları bulgular bölümünde detaylı olarak sunulmuştur.

\section{Etik Kurallara Uygunluk}

$\mathrm{Bu}$ araştırmanın uygulamaları gerçekleştirilirken araştırma ve yayın etiği kurallarına uygun davranılmıştır. Veri toplama sürecinde araştırma sonuçlarının sadece yürütülen araştırmanın amacı kapsamında kullanılacağı örneklemi oluşturan öğrencilere ifade edilmiştir. Birinci yazarın doktora tez çalışmasının bir kısmı kapsamında gerçekleştirilen uygulamalar için Kilis İl Milli Eğitim Müdürlüğünden resmi izinler alınmıştır. 


\section{Verilerin Analizi}

Elde edilen veriler analiz edilmek üzere Excel programına, öğrencilerin sorulara verdikleri doğru yanıtları için bir (1), yanlış verdikleri yanıtları için sıfır (0) girilmiştir. Soru havuzunda kırk soru yer aldığ 1 için toplam puan da kırk üzerinden değerlendirilmiştir. Toplam puanlar düşükten yükseğe doğru sıralanmıştır. Bu sıralanan puanların alttan ve üstten olmak üzere \%27'lik kısımları alınarak alt ve üst grup belirlenmiştir. Test Analiz Programı (TAP), verilerin doğrudan programa girilmesine, giriş dosyasından veri okumasına veya metin dosyalarından veri aktarmasına olanak tanıyan bir programdır (Brooks \& Johanson, 2003). Bu araştırmada, maddelerin veri analizi 1 ve 0 şeklindeki veri setleri için madde analizi yapabilen bir program olan TAP ile yapılmıştır. Testin tamamının ve testte yer alan soruların her birinin madde analizleri gerçekleştirilirken TAP kullanılmıştır. $\mathrm{Bu}$ analizler kapsamında hesaplanan maddetoplam korelasyon değerlerine, madde güçlük ve madde ayırt edicilik indekslerine ilişkin veriler Tablo 4'te verilmiştir.

\section{Çevre Başarı Testi’nin (ÇBT) Geliştirilme Süreci}

Çevre Başarı Testi geliştirilirken izlenen aşamalar bulunmaktadır. Öncelikle soru havuzu oluşturulmuş ve bu sorular uzman görüşüne sunulmuştur. Daha sonra pilot uygulamalar gerçekleştirilmiş ve bu uygulamalardan elde edilen veriler geçerlik ve güvenirlik analizlerine tabi tutularak teste nihai hali verilmiştir. Geçerlik ve güvenirlik analizi verileri çalışmanın bulgular bölümünde detaylı olarak sunulmuştur.

\section{Soru Havuzunun Oluşturulması}

2018 Fen Bilimleri Dersi Öğretim Programı’nda 5. sınıf “İnsan ve Çevre” ünitesi için sekiz tane kazanım yer almaktadır. Bu kazanımların bilişsel düzeyleri ile ilgili üç öğretim üyesinin uzman görüşü alınmıştır. Soru havuzu oluşturulduktan sonra testteki soruların, ünitenin kazanımlarına uygunluğu, dil açısından anlaşılırlığg, yapı, kapsam ve görünüş geçerliği ile ilgili altı uzmanın görüşüne başvurulmuştur (Tablo 3). Tablo 2'de üniteye ait kazanımlar ve bilişsel düzeyleri verilmiştir. Soru havuzu hazırlanırken farklı yayınevlerinin test kitapları, okullarda kullanılan ders ve çalışma kitapları detaylı olarak 
incelenmiştir. Soru havuzunda herhangi bir kaynaktan doğrudan alınmış soru bulunmamaktadır. Tüm sorular araştırmacılar tarafından hazırlanmıştır. Kazanımların her birisi için beş soru hazırlanmıştır. Bu şekilde kırk sorudan oluşan testte yer alan sorular dört seçeneklidir. Ayrıca, çalışmanın ilerleyen bölümlerinde sunulan pilot uygulama ve testin son halinde yer alan soruların numarası da Tablo 2'de yer almaktadır. 
Tablo 2. İnsan ve Çevre Ünitesi Kazanımları ve Bilişsel Düzeyleri

\begin{tabular}{|c|c|c|c|c|}
\hline & Kazanımlar & Bilişsel Düzey & $\begin{array}{l}\text { Pilot için Soru } \\
\text { Numaraları }\end{array}$ & $\begin{array}{l}\text { Son Hali için Soru } \\
\text { Numaraları }\end{array}$ \\
\hline 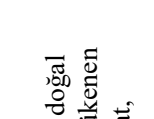 & $\begin{array}{l}\text { F.5.6.1.1. Biyoçeşitliliğin } \\
\text { doğal yaşam için önemini } \\
\text { sorgular }\end{array}$ & Değerlendirme & $1,2,29,33,35$ & 1,27 \\
\hline 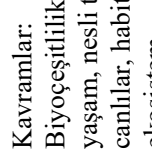 & $\begin{array}{l}\text { F.5.6.1.2. Biyoçeşitliliăgi } \\
\text { tehdit eden faktörleri, } \\
\text { araştırma verilerine dayalı } \\
\text { olarak tartışır }\end{array}$ & Değerlendirme & $3,9,16,20,39$ & $2,6,12,19,22$ \\
\hline 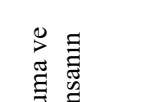 & $\begin{array}{l}\text { F.5.6.2.1. "İnsan ve Çevre" } \\
\text { arasındaki etkileşimin } \\
\text { önemini ifade eder }\end{array}$ & Kavrama & $\begin{array}{l}5,10,17,25, \\
28\end{array}$ & $3,7,13,25$ \\
\hline 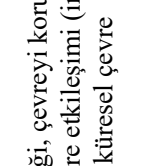 & $\begin{array}{l}\text { F.5.6.2.2. Yakın } \\
\text { çevresindeki veya } \\
\text { ülkemizdeki bir çevre } \\
\text { sorununun çözümüne } \\
\text { ilişkin öneriler sunar }\end{array}$ & Sentez & $\begin{array}{l}4,11,19,34, \\
36\end{array}$ & 15,17 \\
\hline 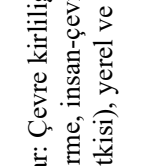 & $\begin{array}{l}\text { F.5.6.2.3. İnsan faaliyetleri } \\
\text { sonucunda gelecekte } \\
\text { oluşabilecek çevre } \\
\text { sorunlarına yönelik } \\
\text { çıarımda bulunur }\end{array}$ & Analiz & $\begin{array}{l}6,12,23,27, \\
32\end{array}$ & $9,20,23,24$ \\
\hline 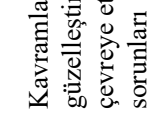 & $\begin{array}{l}\text { F.5.6.2.4. İnsan-çevre } \\
\text { etkileşiminde yarar ve } \\
\text { zarar durumlarını örnekler } \\
\text { üzerinde tartışır }\end{array}$ & Değerlendirme & $\begin{array}{l}7,13,22,26, \\
30\end{array}$ & $5,16,18$ \\
\hline 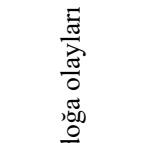 & $\begin{array}{l}\text { F.5.6.3.1. Doğal süreçlerin } \\
\text { neden olduğu yıkıcı doğa } \\
\text { olaylarını açıklar }\end{array}$ & Kavrama & $\begin{array}{l}8,14,24,38, \\
40\end{array}$ & $4,10,21,26$ \\
\hline 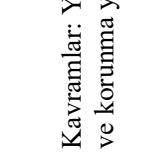 & $\begin{array}{l}\text { F.5.6.3.2. Yıkıcı doğa } \\
\text { olaylarından korunma } \\
\text { yollarını ifade eder }\end{array}$ & Kavrama & $\begin{array}{l}15,48,21,31, \\
37\end{array}$ & $8,11,14$ \\
\hline
\end{tabular}

\section{Uzman Görüşü Alınması}

Oluşturulan testteki soruların ünitenin kazanımlarına uygunluğu, dil açısından anlaşı1ırlığı, yapı, kapsam ve görünüş geçerliğinin sağlanması için uzman görüşleri alınmıştır. Tablo 3 'te uzmanlara ait demografik bilgiler verilmiştir. Uzmanların görüşü hazırlanan uzman görüş formu aracılığıyla alınmıştır. Bu formda soruların her biri için 
hazırlanan tablolarda uzmanlardan "Uygun, Düzeltilmeli veya Çıkarılmalı" seçeneklerini kullanmaları ve gerekli açıklamaları yazarak geri bildirimde bulunmaları istenmiştir. Bir uzmanın görüşü telefonla alınırken diğer uzmanlarla yüz yüze görüşmeler yapılmıştır.

Tablo 3. Uzmanların Demografik Bilgileri

\begin{tabular}{lll}
\hline Kodları & Cinsiyetleri & Uzmanlık Alanları \\
\hline 1 & Erkek & Biyoloji Eğitimi \\
2 & Erkek & Biyoloji Eğitimi \\
3 & Kadın & Fen Eğitimi \\
4 & Kadın & Türkçe Eğitimi \\
5 & Erkek & Fen Bilimleri Öğretmeni \\
6 & Erkek & Fen Bilimleri Öğretmeni \\
\hline
\end{tabular}

Testteki sorulara verilen uzman geri bildirimlerinin kapsam geçerliği için tutarlılığı Kendall W uyum katsayısı ile hesaplanmıştır. Uzmanlar, testten çıkarılması gerektiğini düşündüğü sorular için bir puan; düzeltilmesi gerektiğini düşündüğü sorular için iki puan; uygun olduğunu düşündüğü sorular için üç puan şeklinde değerlendirme yapmışlardır. Test için hesaplanan Kendall W uyum katsayısının 0,84 olması yani bire yakın ve anlamlılık değerinin de 0,05 'ten küçük olması kapsam geçerliği noktasında uzmanların ortak görüşlerinin varlığına işaret etmektedir (Karagöz, 2017).

Testin amac1, kapsamı, yanıtlama yönergesinin öğrenci düzeyine uygun olup olmadığ1, testin adı ile içeriğinin uyumu bağlamında görünüş geçerliği konusunda da uzman görüşüne başvurulmuştur. Uzmanların testin görünüş geçerliği açısından aynı puanlamaları yapması sebebiyle Kendall W uyum katsayısı "1” olarak hesaplanmıştır $(\mathrm{p}<, 05)$. Uzmanların geri bildirimlerinden sonra madde çıkarılmamış ancak birkaç soruda uzmanların yönlendirdiği düzeltmeler yapılmıştır.

\section{ÇBT Pilot Uygulamalar}

Pilot uygulamalar öğrencilerin soruları anlayıp anlamadıklarının netleştirilmesi, anlamakta zorlandıkları kavramların ortaya çıkarılması, çeldiricilerin işlevselliği, testin yanıtlanma süresinin tespiti gibi konularda karar vermeyi kolaylaştırmak için birden 
fazla kez yapılmıştır. Tüm uygulamaları birinci yazar üç farklı ortaokulda gerçekleştirmiştir.

\section{ÇBT Pilot Öncesi Uygulama 1}

Pilot Öncesi Uygulama 1, 6. sınıftaki 18 öğrenci ile 55-70 dakika arasında gerçekleştirilmiştir. Bu uygulamada araştırmacı öğrencilere bu testin bilimsel bir çalışma kapsamında yapıldığını ve değerlendirmelerin onların ders notlarını etkilemeyeceğini açıklamıştır. Öğrencilerden anlamakta sıkıntı yaşadıkları kavramları ve hangi soruda yer aldıklarını işaretlemeleri istenmiş ve öğrencilerin geri bildirimleri doğrultusunda değişiklikler yapılmıştır. Örneğin, bir sorunun seçenekleri arasında yer alan "kobay" kelimesi pek çok öğrenci tarafından anlaşılamamıştır. Bu sebeple, ifade "laboratuvar deneylerinde kullanılan hayvanlar" şeklinde değiştirilmiştir. Bu uygulamadan elde edilen veriler için madde analizleri yapılmış fakat testten soru çıkarılmamıştır.

\section{ÇBT Pilot Öncesi Uygulama 2}

Öğrencilerin tek oturumda testi yanıtlamalarının onlar için sıkıcı ve yorucu olduğu Pilot Öncesi Uygulama 1'deki öğrenciler tarafından ifade edildiğinden Pilot Öncesi Uygulama 2'de test yarıya ayrılarak uygulanmıştır. İki ders saati olarak yapılan uygulamanın birinci ders saatinde öğrenciler ilk yirmi soruyu yanıtladıktan sonra kâğıtları toplanmış ve on dakika ara verilmiştir. Bu aranın bitiminde diğer yirmi soru dağıtılarak 7. sınıfta okuyan 22 öğrenci ile uygulama tamamlanmıştır. $\mathrm{Bu}$ şekilde öğrenciler yaklaşık 70 ile 80 dakika arasındaki sürelerde testi yanıtlamışlardır. $\mathrm{Bu}$ uygulamada da bir önceki uygulamada yapılan uyarılar öğrencilere yapılmıştır. Madde analizleri sonucu bazı çeldiricilerin çok az işaretlendiği, bazı soruların ise çok kolayłzor olduğu tespit edilmiş ve bu seçenekler ve sorular üzerinde düzenlemeler yapılmıştır.

\section{ÇBT Pilot Uygulama}

Çevre Başarı Testi, 6., 7. ve 8. sınıfa devam eden 273 öğrenciye iki ders saatinde uygulanmıştır. Birinci ders saatinde öğrenciler ilk yirmi soruyu yanıtladıktan sonra kâğıtları toplanmış, on dakika ara verilmiş ve ikinci ders saatinde diğer yirmi soru 
öğrencilere dağıtılmıştır. Bu şekilde, öğrenciler yaklaşık 65 ile 80 dakika arasındaki sürelerde testi yanıtlamışlardır. Bu uygulamalar esnasında sınıflarda sınav ortamı oluşturularak her öğrencinin testi bireysel cevaplandırması sağlanmıştır. Çevre Başarı Testi'ne ait kazanımlar ve bu kazanımlar ile ilişkilendirilen soruların numaraları Tablo 2'de verilmiştir.

\section{BULGULAR}

Bu çalışmada, 5. sınıf Fen Bilimleri dersi "İnsan ve Çevre" ünitesine ilişkin 27 çoktan seçmeli soru içeren “Çevre Başarı Testi” geliştirilmiş̧tir.

\section{ÇBT Güvenirlik ve Geçerlik Analizleri}

Çevre Başarı Testi (ÇBT) pilot uygulamasından elde edilen toplam puanlar düşükten yükseğe doğru sıralanmıştır. Bu sıralanan puanların alttan ve üstten olmak üzere $\% 27^{\prime}$ lik kısımları alınarak 74 kişilik alt ve 74 kişilik üst grup belirlenmiştir. Bu veriler TAP aracılığı ile madde analizine tabi tutulmuştur. Hesaplanan madde-toplam korelasyon değerleri, madde ayırt edicilik ve madde güçlük indeksleri Tablo 4'te verilmiştir.

\section{Madde Güçlük Indeksi}

Bir testteki maddelerin \soruların doğru cevaplanma yüzdesini gösteren madde güçlük indeksi 0'a yaklaşırken maddenin zorlaştığı; 1'e yaklaşırken kolaylaştığını gösterir. Başarı testlerinde ise 0,20 ile 0,80 arasında olması beklenmektedir (İlhan \& Hoşgören, 2017). Çevre Başarı Testi'ndeki 2., 17. ve 34. maddelerin güçlük indeksi 0,30 'un altında; 4., 6., 11., 21., 22. ve 35. maddelerin ise 0,85 'in üzerinde olmas1 sebebiyle bu maddelerin testten çıarılmasına karar verilmiştir. $\mathrm{Bu}$ durumda testte yer alan maddelerin güçlük indeks değerleri 0,30 ile 0,85 arasında değişmektedir (Tablo 4). Diğer madde analizleri sonucunda son halinde 27 sorudan oluşan ÇBT'nin ortalama madde güçlük indeksi ise 0,62 olarak hesaplanmıştır. Bu değer ÇBT'nin, orta güçlükte bir test olduğu şeklinde yorumlanabilir. 
Madde Ayırt Edicilik Indeksi

Testte yer alan maddelerin istenilen özelliği ölçmesi, maddelerin geçerli olup olmamasını tespit etmede yararlanılan madde ayırt edicilik indeksi -1 ile +1 arasında değerler alır. Bir teste seçilen maddenin ayırt edicilik indeksi 0,19 ve altında ise o çok zayıf bir madde olduğundan testten çıkarılmalı; 0,20-0,29 arasında ise madde düzeltilmeli ve geliştirilmeli; 0,30-0,39 arasında ise oldukça iyi ancak yine de geliştirilebilir; 0,40 ve üzerinde ise ayırt ediciliği çok iyi madde olarak yorumlanır (Karslı \& Ayaz, 2013; Tosun \& Taşkesenligil, 2011).

ÇBT'ye seçilen maddelerin madde ayırt edicilik indekslerinin 0,30 ve üzeri olması esas alınmıştır (Tablo 4). Diğer madde analizleri sonucunda son halinde 27 sorudan oluşan ÇBT'nin ortalama madde ayırt edicilik indeksi 0,47 olarak hesaplanmıştır.

Madde-Toplam Korelasyonu

Tablo 4'te madde- toplam korelasyon değerlerinin 0,00 ile 0,77 arasında değiş̧tiği görülmektedir. Bir testteki her bir maddeye ait puanla testin toplam puanı arasındaki ilişkiyi açıklayan madde- toplam korelasyon değerinin ise 0,25 'ten yüksek olması beklenir (Karagöz, 2017). Bu testte yer alan altı maddenin madde-toplam korelasyon değerlerinin 0,25 'in altında olduğu görülmüştür (Tablo 4). Bu maddelere testte yer verilmemiştir.

\section{KR-20 Güvenirlik Katsayısı}

0 ile 1 arasında değer alan KR-20, başarı testlerinin güvenirliğini hesaplamada kullanılır ve testin güvenirliği bakımından 0,70'in üzerinde olması beklenir (Metin, 2015). Bu araştırmada Çevre Başarı Testi için KR-20 değeri 0,84 olarak hesaplanmıştır. Bu değer testin güvenilir olduğuna işaret etmektedir. 
Tablo 4. Madde Güçlük İndeksi, Madde Ayırt Edicilik İndeksi ve Madde- Toplam Korelasyon Değerleri

\begin{tabular}{|c|c|c|c|}
\hline Madde No & $\begin{array}{c}\begin{array}{c}\text { Madde Güçlük } \\
\text { İndeksi }\end{array} \\
\end{array}$ & $\begin{array}{c}\text { Madde Ayırtedicilik } \\
\text { İndeksi }\end{array}$ & $\begin{array}{c}\text { Madde- Toplam } \\
\text { Korelasyonu Değeri }\end{array}$ \\
\hline 1 & 0,31 & 0,36 & 0,31 \\
\hline 2 & $0,26^{*}$ & 0,37 & 0,36 \\
\hline 3 & 0,44 & 0,55 & 0,50 \\
\hline 4 & $0,87 *$ & $0,19 *$ & 0,39 \\
\hline 5 & 0,76 & 0,41 & 0,49 \\
\hline 6 & $0,88^{*}$ & 0,34 & 0,77 \\
\hline 7 & 0,84 & 0,35 & 0,63 \\
\hline 8 & 0,74 & 0,41 & 0,48 \\
\hline 9 & 0,55 & 0,41 & 0,33 \\
\hline 10 & 0,45 & 0,52 & 0,48 \\
\hline 11 & $0,88^{*}$ & $0,28 *$ & 0,61 \\
\hline 12 & 0,63 & 0,52 & 0,44 \\
\hline 13 & 0,33 & 0,32 & $0,23 *$ \\
\hline 14 & 0,37 & 0,46 & 0,37 \\
\hline 15 & 0,68 & 0,41 & 0,37 \\
\hline 16 & 0,46 & 0,41 & 0,32 \\
\hline 17 & $0,19^{*}$ & $0,24 *$ & $0,22 *$ \\
\hline 18 & 0,36 & 0,43 & 0,35 \\
\hline 19 & 0,58 & 0,36 & 0,26 \\
\hline 20 & 0,64 & 0,64 & 0,65 \\
\hline 21 & $0,90 *$ & $0,17 *$ & 0,44 \\
\hline 22 & $0,86^{*}$ & 0,32 & 0,63 \\
\hline 23 & 0,73 & 0,59 & 0,70 \\
\hline 24 & 0,37 & $0,15^{*}$ & $0,06^{*}$ \\
\hline 25 & 0,49 & 0,46 & 0,41 \\
\hline 26 & 0,83 & 0,32 & 0,51 \\
\hline 27 & 0,71 & 0,59 & 0,61 \\
\hline 28 & 0,61 & 0,53 & 0,46 \\
\hline 29 & 0,30 & $0,10^{*}$ & $0,00^{*}$ \\
\hline 30 & 0,81 & 0,46 & 0,68 \\
\hline 31 & 0,70 & 0,58 & 0,64 \\
\hline 32 & 0,64 & 0,51 & 0,49 \\
\hline 33 & 0,54 & 0,40 & 0,34 \\
\hline 34 & $0,23 *$ & $0,08^{*}$ & $0,09 *$ \\
\hline 35 & $0,89 *$ & $0,27 *$ & 0,65 \\
\hline 36 & 0,78 & 0,44 & 0,56 \\
\hline 37 & 0,38 & $0,23^{*}$ & $0,21 *$ \\
\hline 38 & 0,78 & 0,35 & 0,44 \\
\hline 39 & 0,58 & 0,45 & 0,39 \\
\hline 40 & 0,65 & 0,39 & 0,44 \\
\hline
\end{tabular}

*Testten çıkarılan sorular 
Çevre Başarı Testi'ne madde seçilirken madde güçlük indeksine (2., 6. ve 22. maddeler); madde-toplam korelasyonuna göre (13. madde); madde güçlük ve madde ayırt edicilik indekslerinin her ikisine göre (4., 11., 21. ve 35. maddeler); madde ayırt edicilik indeksi ve madde-toplam korelasyonunun her ikisine göre (24., 29. ve 37. maddeler); madde güçlük indeksi, madde ayırt edicilik indeksi ve madde- toplam korelasyonunun her üçüne göre (17. ve 34. maddeler) kabul edilen değer aralıklarını sağlamayan maddeler testten çıkarılmıştır. Bu maddelere ait değerler Tablo 4'te verilmişsir.

\section{Teste Son Halinin Verilmesi}

Çevre Başarı Testi madde analizleri sonucu testten on üç (2., 4., 6., 11., 13., 17., 21., 22., 24.,29., 34. 35. ve 37.) madde çıkarılmıştır. Son hali ile yirmi yedi sorudan oluşan testin ortalama madde ayırt edicilik indeksi 0,47 ; ortalama madde güçlüğü 0,62 olarak hesaplanmıştır. Ayrıca KR-20 güvenirlik katsayısı 0,82 olarak hesaplanmıştır. Teste seçilen maddeler rasgele sıralanmıştır. Bu maddelerin ait oldukları kazanımlar Tablo 2'de görülmektedir.

\section{TARTIŞMA ve SONUÇ}

Bu çalışmada 5. sınıf "İnsan ve Çevre" ünitesine ilişkin öğrencilerin akademik başarı düzeyleri hakkında ölçme ve değerlendirme yapabilmek için geçerliği ve güvenirliği test edilmiş bir başarı testinin geliştirilmesi amaçlanmıştır. Bu amaç kapsamında başarı testinin oluşturulma aşamaları takip edilmiştir. İlgili alanyazında fen bilimleri eğitiminin farklı konuları için benzer şekilde başarı testi geliştirme aşamalarının izlendiği araştırmalar olduğu görülmektedir (Ahmad, Sultana \& Jamil, 2020; Akbulut \& Çepni, 2013; Dede \& Keleş, 2020; Kargın \& Gül, 2021; Nacaroğlu, Bektaş \& Kızkapan, 2020; Üçüncü \& Sakız, 2020; Soylu, Karamustafaoğlu \& Karamustafaoğlu, 2020).

Öncelikle ÇBT’nin amacı belirlenmiş ve kapsam geçerliğini sağlaması açısından belirtke tablosu hazırlanmış ve soru havuzu oluşturulmuştur. Soru havuzunda sekiz 
kazanımın her biri için beşer adet olmak üzere toplam kırk adet çoktan seçmeli ve dört seçenekli sorular yer almıştır. Alınan uzman görüşleri doğrultusunda testten soru çıkarılmamıştır. Çeldiricilerin işlevselliği, görünüş geçerliği gibi konularda fikir sahibi olabilmek adına test için iki kez pilot öncesi uygulama yapılmıştır. Bu uygulamalarda madde atılmamış, bazı çeldiricilerin çok az işaretlendiği, bazı soruların ise çok kolayłzor olduğu tespit edilmiş ve bu seçenekler ve sorular üzerinde düzenlemeler yapılmıştır. Testin pilot uygulaması ise, 6., 7. ve 8. sınıfa devam eden 273 öğrenciyle gerçekleştirilmiş ve elde edilen veriler madde analizlerine tabi tutulmuştur.

Madde analizleri sonucu 27 sorudan oluşan ÇBT'nin ortalama madde güçlüğü 0,62 ; ortalama madde ayırt edicilik indeksi 0,47 ; KR-20 güvenirlik katsayısı 0,82 olarak hesaplanmıştır. Bu değerler oluşturulan testin orta güçlükte ve ayırt ediciliğinin çok iyi olduğuna; KR-20 güvenirlik katsayısının 0,70 'in üzerinde olması da güvenirliğinin yüksek olduğuna işaret etmektedir (Büyüköztürk, 2018). ÇBT’nin 2018 Fen Bilimleri Dersi Öğretim Programı 5. sınıf "İnsan ve Çevre" ünitesinin tüm kazanımlarına dair soru içermesi ve geçerliği ve güvenirliği sağlanmış bir başarı testi olması bakımından alanyazına katkı sağlayacağı düşünülmektedir.

Ülkemizde öğrenci seçme ve yerleştirme sınavlarının da çoktan seçmeli testlerden oluştuğu düşünülürse bu araştırma kapsamında geliştirilen testin öğrencilerinin sınava hazırlık sürecinde öğretmenleri tarafindan kullanılması yararlı olabilir. Ünitenin kazanımları ve uygulanan test arasında yüksek düzeyde uyum olması öğrencilerin daha başarılı olmalarını sağlar (Akbulut \& Çepni, 2013). Bir üniteyi ve kazanımlarının hepsini kapsayacak şekilde oluşturulan testler, o ünitenin öğrenciler tarafından öğrenilme seviyesini daha verimli şekilde tespit etmeyi sağlaması açısından başarıyı ölçmede daha etkilidir (Kara \& Çepni, 2011). Bu sebeple, ÇBT'yi öğretmenler üniteye ilişkin öğrencilerinin başarı düzeylerini belirlemek için kullanabilir.

ÇBT, öğrencilerin 5. sınıf çevre konuları ile ilgili bilgi seviyelerini ve eksikliklerini belirleyerek, öğrenme etkinliklerinin düzenlenmesinde eğitimcilere yardımcı olabilir. 
Başarı testleri konu ile ilgili öğrencilerin performanslarına dair bir fikir edinmek için oldukça verimli olmasına rağmen eleştirel ve yaratıcı düşünme gibi becerileri göz ardı edebilir. Bu sebeple, öğretmenler testi uyguladıktan sonra, testte yer alan sorularla ilgili sınıf içi tartışmalar yürüterek, öğrencilerinin problem çözme, değerlendirme, yansıtma gibi becerilerinin geliştirilmesine katkı sağlayabilir. Bu araştırmada geliştirilen başarı testinde yer alan madde ve seçeneklerin günlük yaşamla ile ilişkilendirilerek hazırlanmış olmasının bu tartışmalarda işlevsel olacağı düşünülmektedir.

Belirli bir yöntemin bu ünite ile ilgili kazanımların öğrenilmesine etkisi hakkında çalışmalar yapan lisansüstü düzeydeki araştırmacılar çalışmalarında veri toplama aracı olarak ÇBT'yi kullanabilir. Farklı konularda başarı testi geliştirmeye ihtiyaç duyan araştırmacılar bu testin geliştirme aşamalarını takip ederek test geliştirme süreçlerini yürütebilir. 


\section{KAYNAKLAR}

Ahmad, S., Sultana, N., \& Jamil, S. (2020). Considerations for constructing and validating biology achievement test at secondary level. US-China Education Review B, 10(1), 13-25. doi: 10.17265/21616248/2020.01.002

Akbulut, H. İ. \& Çepni, S. (2013). Bir üniteye yönelik başarı testi nasıl geliştirilir? İlköğretim 7. sınıf kuvvet ve hareket ünitesine yönelik bir çalışma. Amasya Üniversitesi Ĕgitim Fakültesi Dergisi, 2(1), 18-44.

Armağan, F. Ö. (2006). İlköğretim 7-8. sını öğrencilerinin çevre eğitimi ile bilgi düzeyleri (Kırıkkale il merkezi örneklemi). (Yayınlanmamış yüksek lisans tezi). Gazi Üniversitesi, Ankara.

Brooks, G. P., \& Johanson, G. A. (2003). TAP: Test analysis program. Applied Psychological Measurement. 27(4), 303-304.

Büyüköztürk, Ş., (2018). Sosyal bilimler için veri analizi el kitabı istatistik, araştırma deseni SPSS uygulamalart ve yorum. Ankara: Pegem A yayıncilık.

Çardak, Ç. S., \& Selvi, K. (2018). Öğretim ilke ve yöntemleri dersi için bir başarı testi geliştirme süreci. Akdeniz Ë̆itim Araştırmaları Dergisi, 12(26), 379-406.

Dede, H., \& Keleş, İ. H. (2020). Saf madde, karışımlar ve karışımların ayrılması konularında yaşam temelli başarı testinin geliştirilmesi. Gazi Üniversitesi Gazi Ĕgitim Fakültesi Dergisi, 40(3), 797-825.

Fidan, E. (2013). İlkokul öğrencileri için matematik dersi sayılar ögrenme alanında başarı testi geliştirilmesi. (Yayınlanmamış yüksek lisans tezi). Ankara Üniversitesi, Ankara.

İlhan, N., \& Hoşgören, G. (2017). Fen bilimleri dersine yönelik yaşam temelli başarı testi geliştirilmesi: Asit baz konusu. Fen Bilimleri Öğretimi Dergisi, 5(2), 87-110.

Kara, Y., \& Cepni, S. (2011). Investigation the alignment between school learning and entrance examinations through item analysis. Journal of Baltic Science Education, 10(2), 73-86.

Karagöz, Y. (2017). SPSS ve AMOS 23 uygulamalt istatistiksel analizler. Ankara: Nobel Yayıncilik.

Kargın, P. D., \& Gül, Ş. (2021). Altıncı sınıf "Vücudumuzdaki Sistemler ve Sağlığı" ünitesine yönelik bir başarı testi geliştirilmesi. Ihlara Eğitim Araştırmaları Dergisi, 6(1), 1-26.

Karip, E. (2012). Ölçme ve değerlendirme. Ankara: Pegem Akademi Yayıncılık.

Karslı, F., \& Ayaz, A. (2013). Fen ve teknoloji dersi öğretmen adaylarının bilimsel süreç becerilerinin ölçülmesine ilişkin bir test geliştirme çalışması. Journal of Turkish Science Education, 10(2), 66-84. http://repository.bilkent.edu.tr/handle/11693/20717

Kubanç, Y. (2019). Achievement test development study for step concept. European Journal of Education Studies, 6(6), 208-222. 
Metin, M. (2015). Nicel veri toplama araçları. M. Metin (Ed.), Kuramdan uygulamaya eğitimde bilimsel araştırma yöntemleri (ss. 161-214). Ankara: Pegem A Yayıncılık.

Nacaroğlu, O., Bektaş, O., \& Kızkapan, O. (2020). Madde döngüleri ve çevre sorunları konusunda başarı testi geliştirme: Geçerlik ve güvenirlik çalışması. Kastamonu Ë̆itim Dergisi, 28(1), 36-51.

Opara, I. M., \& Magnus-Arewa, E. A. (2017). Development and validation of mathematics achievement test for primary school pupils. British Journal of Education, 5(7), 47-57.

Özaşkın Arslan, A. G., \& Karamustafaoğlu, S. (2019). 2018 Fen bilimleri öğretim programı kapsamındaki 7. sınıf güneş sistemi ve ötesi ünitesine yönelik bir başarı testi geliştirme. Ondokuz Mayıs Üniversitesi Eğitim Fakültesi Dergisi, 38(2), 172-205.

Patton, M. Q. (2014). Qualitative research and evaluation methods. CA: Sage.

Soylu, Ü. İ., Karamustafaoğlu, S., \& Karamustafaoğlu, O. (2020). 6. sınıf "Madde ve Isı" ünitesi başarı testi geliştirme: Geçerlik ve güvenirlik. Ihlara Ĕgitim Araştırmaları Dergisi, 5(2), 270-292.

Tavşancıl, E. (2010). Tutumların ölçülmesi ve SPSS ile veri analizi. Ankara: Nobel Yayıncılık.

Tosun, C., \& Taşkesenligil, Y. (2011). Revize edilmiş Bloom'un taksonomisine göre çözeltiler ve fiziksel özellikleri konusunda başarı testinin geliştirilmesi: Geçerlik ve güvenirlik çalışması. Kastamonu Eğitim Dergisi, 19(2), 499-522. https://dergipark.org.tr/en/download/article-file/817458

Üçüncü, G., \& Sakız, G. (2020). Başarı testi geliştirme süreci: İlkokul dördüncü sınıf maddeyi tanıyalım ünitesi örneği. Kastamonu Eğitim Dergisi, 28(1), 82-94.

\section{ORCID}

Özge ÇIÇEK ŞENTÜRK iD https://orcid.org/0000-0002-2630-9466

Mahmut SELVI $\mathrm{https} / / /$ orcid.org/0000-0002-9704-1591 


\section{SUMMARY}

\section{Introduction}

There are eight learning outcomes in the unit of "Human and Environment" in 5th grade of secondary school. With these learning outcomes, it is aimed that students gain basic information about the environment, understand the relationship between humans and the environment, question the causes and consequences of environmental problems, and know destructive natural events and ways of protection. It is very important to give feedback to the student within the scope of these learning outcomes. An achievement test on this topic can be used for feedback.

This study aims to develop an achievement test whose validity and reliability have been tested that can be used as a measurement and evaluation tool for the 5th grade "Human and Environment" unit and to present all its stages in detail.

The research questions of this study are as follows:

1. What is the reliability level of the achievement test developed for the 5th grade "Human and Environment" unit?

2. Is the achievement test developed for the 5th grade "Human and Environment" unit valid?

\section{Method}

In this study, the survey method was used as a research method. Criterion sampling, one of the purposeful sampling methods, was used to determine the sample (Patton, 2014). As a criterion, having learned the "Human and Environment" unit in science course in previous years was taken into account. Therefore, the sample is secondary school 6th, 7th, and 8th-grade students. Development stages of the Environmental Achievement Test: creating a pool of questions, obtaining expert opinions, pilot applications, validity and reliability analyses, finalization of the test.

First, a question pool of 40 questions was prepared for the test. Expert opinion was sought to determine the suitability of these questions in terms of unit gains and their comprehensibility in terms of language and to ensure the validity of the content, construct, and face. More than one pre-application has been made including Pre-pilot Practice-1, Pre-pilot Practice-2, and Pilot Practice.

The pilot practice of the test was applied to 273 students in the 6th, 7th, and 8th-grade, and item analysis was performed on the data obtained. The data analysis of the items was done with the Test Analysis Program. Using TAP, the item difficulty index, item discrimination index, item-total correlation of the test and each question, and KR-20 reliability coefficient were calculated.

\section{Findings}

Item difficulty index values of the questions in the test are between 0.40 and 0.80 . The average item difficulty index of the test was calculated as 0.60. The item discrimination index of the items 
selected for the test is 0.30 and above. The item-total correlation value of the items in the test is higher than 0.25 .

As a result of the item analysis, items 2, 4, 6, 11, 13, 17, 21, 22, 24, 29, 34, 35, and 37 were excluded from the test with 40 questions. After these items were removed, the test consisted of 27 items.

\section{Conclusions}

The Environmental Achievement Test developed includes the acquisitions of the 5th grade "Human and Environment" unit of the 2018 science curriculum. As a result, The KR-20 value of the test is 0.82; item difficulty index value 0.62; item discrimination index was calculated as 0.47 . These values show that the test is reliable, medium-difficult, and distinctive.

Teachers can use this test to determine the success levels of their students regarding the unit. It can be used as a data collection tool in the studies of postgraduate researchers on the relevant subject. Researchers who need to develop success tests on different subjects can follow the development stages of this test and carry out their processes. 


\section{ORTAOKUL 5. SINIF ÇEVRE BAŞARI TESTI}

1. "Bir bölgedeki bitki ve hayvan türlerinin sayıca zenginliği günlük yaşamımızın pek çok alanında yarar sağlar.” ifadesini aşağıdakilerden hangisi desteklememektedir?

A) Bitki ve hayvan türlerinin sayıca zenginliği canlı ve cansız varlıklar arasındaki dengenin korunmasını sağlar.

B) Büyükbaş hayvan sayısının artışı mera alanlarının artmasını sağlar.

C) Çam, meşe, palamut türü ağaçlar ormancılık faaliyetlerinde kullanılır.

D) Bazı hayvanlar tıp, eczacılık vb. alanlardaki laboratuvar deneylerinde kullanılır.

2. Özgür: Dünyada ve ülkemizde aşırı nüfus artışı, plansız kentleşme, çevre kirliliği, tarımda kimyasal maddelerin kullanılması, aşırı avlanma gibi faaliyetlerden dolayı biyoçeşitlilik her geçen gün azalmaktadır. Sence biyoçeşitliliğin korunması için ne yapılabilir?

Deniz:

Biyoçeşitliliğin korunması için Deniz'in hangi doğru öneride bulunması gerekir?

A) Doğal su kaynakları sadece içme suyu olarak kullanılmalıdır.

B) Bataklıklar kurutularak tarım alanları sayısı arttırılmalıdır.

C) Nüfus artışına bağlı olarak artan barınma ihtiyacını karşılamak için ormanlık alanlar yerleşime açılmalıdır.

D) Organik tarım faaliyetleri yapan çiftçi sayısı arttırılmalıdır.

3. Aşağıdaki tabloda "İnsan ve Çevre" arasındaki etkileşim ile ilgili bazı ifadeler verilmiştir.

\begin{tabular}{|l|l|}
\hline & Elde edilen ürün sayısını arttırmak için zirai gübre kullanılmalıdır. \\
\hline $\begin{array}{l}\text { Bazı doğal afetlerin gerçekleşmesinde insanların bilinçsiz davranışlarının da } \\
\text { etkisi vardır. }\end{array}$ \\
\hline Enerji elde etmek için güneş panellerinin kullanılması hava kirliliğine sebep olur. \\
\hline
\end{tabular}

Bu ifadelerden doğru olanların bașına (D) yanlıș olanların bașına (Y) işaretleri konulduğunda kutucukların son görünümü aşağıda verilenlerden hangisi olur?

A)

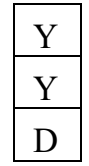

B)

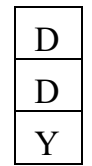

C)

\begin{tabular}{|l|}
\hline $\mathrm{Y}$ \\
\hline $\mathrm{D}$ \\
\hline $\mathrm{Y}$ \\
\hline
\end{tabular}

D)

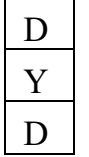


4. Aşağıdakilerden hangisi sel felaketine yol açan etkenler arasında gösterilemez?

A) Toprağın içerdiği su miktarı

B) Deniz seviyesinin yükselmesi

C) Toprak tarafindan emilemeyecek kadar yağmur yağması

D) Ani ve güçlü yağışlar ile karların erimesi

5. Bir proje için toprak kirliliği hakkında doğru bilgilere sahip çalışma arkadaşı bulmak için görüşmeler yapan bir kişi aşağıdaki ifadelerden hangisini verenle beraber çalışmayı tercih etmez?

A) Tarımda kullanılan kimyasal maddelerin insanların tükettiği bitkiler üzerinde birikmesi insan sağlığına zarar verir.

B) Aşırı gübreleme toprağın yapısını bozar.

C) Atık pillerin zararlı etkilerinin önüne geçmek için onları toprağa gömmek gerekir.

D) Toprak kirlenmişse orada yetiştirilen sebze ve meyveler de büyük ihtimalle kirlenmiştir.

6. “Türkiye' de daha önce hiç görülmeyen ve sulak alanlarda yaşayan bir kuş türü olan "Basra Kamçını” isimli kuş ilk kez Iğdır' da görüldü. Uzmanlar bu kuş türünün neslinin belirttiler." sebebiyle tehlike altında olduğunu

Emre, yukarıdaki haberi radyoda dinlerken kısa bir süreliğine elektrik kesilmiş ve yukarıda boşlukla belirtilen ifadeyi duyamamıştır. Sizce haber sunucusu bu sırada aşağıdakilerden hangisini söylemiş olamaz?

A) Sulak alanların büyük oranda yok edilmesi

B) Üreme alanlarının zarar görmesi

C) Göç yolundaki beslenme ve barınma alanlarındaki insan faaliyetleri

D) Doğal alanlar üzerindeki madencilik faaliyetleri

7. Aşağıdaki ifadelerden hangisi insanların çevreye verdikleri zararı azaltmak için yapılabilecek faaliyetlerden biri olarak değerlendirilemez?

A) Organik atıkların toprakta birikmesinin engellenmesi

B) Yeşil alanların yerleşime açılmaması

C) Geri dönüşüm çalışmalarının desteklenmesi

D) Fabrika kurmak için ormanların tahrip edilmemesi 
8.
I. Sakin olmalıyız.
II. Evden dışarı çıkmaya çalışmalıyız.
III. Deprem çantası hazırlamalıyız.

Yukarıdakilerden hangisi depreme evde yakalandığımızda yapmamız gerekenler arasında gösterilemez?
A) I ve III
B) II ve III
C) Yalnız II
D) I, II ve III

9. Bazı böcekler tarlaya ekilen ürünlere zarar vererek elde edilen ürün miktarının azalmasına neden olur. Eğer bu tür sorunlar pek çok çiftçinin başına gelirse bu durum ülke ekonomisine de yansır. Bu durumda çiftçilerin tarım ilaçlarını aşırı miktarda kullanmaları aşağıdaki durumlardan hangisininไhangilerinin gerçekleşmesine yol açar?

I. Yeraltı sularına sızan tarım ilaçları suların kirlenmesine neden olabilir

II. Çevremizdeki böcek biyoçeşitliliği artabilir.

III. Bu ilaçların bulaştığı yemlerle beslenen hayvanlar etkilenebilir.
A) I ve II
B) I ve III
C) II ve III
D) I, II ve III

10.

I. Sıcak hava bölgelerinde soğuk hava ile sicak havanın dar bir alanda aniden yer değiştirmesi ile oluşur.

II. Çok şiddetli bir rüzgâr türüdür.

III. Yıldırım ve şimşek gibi doğa olaylarından sonra görülür.

Yukarıdaki ifadelerden hangileri hortumlar için söylenebilir?
A) I ve II
B) II ve III
C) I ve III
D) I, II ve III

11.

\begin{tabular}{|l|l|}
\hline \multicolumn{1}{|c|}{ Doğal Afet } & \multicolumn{1}{c|}{ Korunma Yolları } \\
\hline a) Deprem & Ağaçlandırma yapılmalıdır. \\
\hline b) Yanardağ Patlaması & Yakın bölgelerinde yerleşim alanları oluşturulmamalıdır. \\
\hline c) Sel & Gece yatarken yatak odalarının kapıları kapatılmamalıdır. \\
\hline d) Heyelan & Eğimli arazilerde bitki örtüsü korunmalıdır. \\
\hline
\end{tabular}

Yukarıdaki tabloda doğal afetler ve korunma yolları verilmiştir. Hangi iki doğal afet yer değiştirirse tablo doğru olur?
A) a ve b
B) a ve c
C) c ve d
D) $b$ ve d 
12. Doğa Koruma ve Milli Parklar Genel Müdürlüğünden bir yetkili, yaptıkları çalışmalar sonucunda biyolojik çeşitliliğin; insan davranışları, artan nüfus, kontrolsüz tüketim alışkanlığı gibi sebeplerden dolayı zarar gördüğünü açıklamıştır. Aşağıdakilerden hangisi bu zararları azaltmaya yönelik yapılabileceklerden biridir?

A) Doğal kaynakların kullanımı arttırılmalıdır.

B) Ağaçları kesip ahşap evler inşa edilerek çevre güzelleştirilmelidir.

C) Nesli tükenme tehlikesi altında olan hayvanların korunması için av yasakları kaldırılmalıdır.

D) Kıyı habitatlarının korunması sağlanmalıdır.

13.

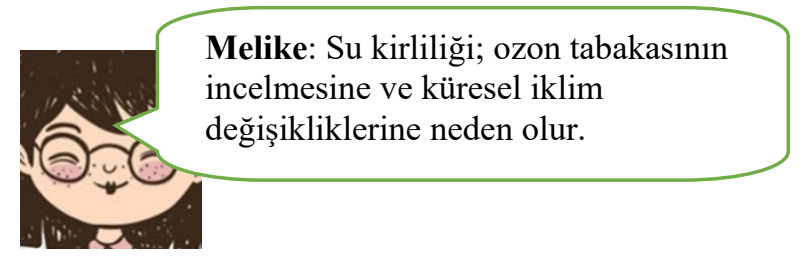

\begin{tabular}{|c|}
\hline $\begin{array}{l}\text { Kerem: İnsanların beslenme, barınma, } \\
\text { 1sınma gibi ihtiyaçlarını karşılarken } \\
\text { doğal kaynakları } \\
\text { tüketmeleri, çevre bilinçsizce } \\
\text { artmasına neden olur. }\end{array}$ \\
\hline
\end{tabular}

Mehmet Öğretmen çevre konulu bir bilgi yarışması düzenlemektedir. Finale kalan Melike ve Kerem'in cevaplarını göz önünde bulundurursanız yarışmanın sonucu hakkında hangisini söyleyebilirsiniz?
A) Kerem kazanmıştır.
B) Melike kazanmıştır.
C) Birinciliği paylaşmışlardır.
D) İkisi de kazanamamıştır.

\section{Aşağıdakilerden hangisi heyelandan korunma yöntemlerinden biridir?}
A) Yamaçlar ve dağlık alanlar yerleşim yerleri olarak tercih edilmemelidir.
B) Düştüğü zaman insana zarar verebilecek mobilyalar duvara sabitlenmelidir.
C) Evdeki gaz ve su vanaları kapatılmalıdır.
D) Binalara sığınak yapımı arttırılmalıdır. 
15. Toprakta zehirli maddelerin artması ile ortaya çıkan kirliliği azaltmak için aşağıdakilerden hangisi yapılabilir?

A) Tarım ilaçlarının topraktan uzaklaştırılarak akarsu, göl ve denizlere karışması sağlanabilir.

B) Pillerin içindeki kimyasalların toprağa karışması sağlanabilir.

C) Çevreye bırakılan sanayi atıkları etrafa dağılmaması için toprağa gömülebilir.

D) Toprağın hayvan dışkısı ile gübrelenmesi sağlanabilir.

16.

I. Temiz su kaynaklarının azalması sadece suda yaşayan canlıları olumsuz etkiler.

II. Doğal afetler ormanların azalmasına neden olur.

III. Zararlı böcekler ve çekirgelerin yok edilmesinde kullanılan kimyasal ilaçlar biyoçeşitliliği olumsuz etkiler.

Yukarıda verilen yargılardan hangileri doğrudur?
A) I ve II
B) I ve III
C) II ve III
D) I, II ve III

17.

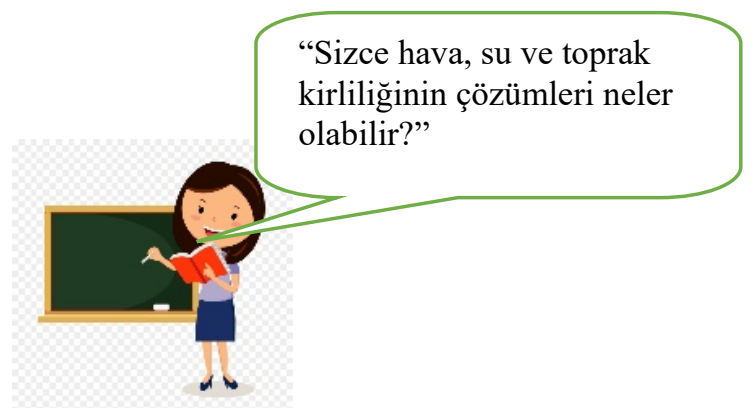

Ada Öğretmenin sorusuna öğrencileri Emir, Elif ve Murat aşağıdaki cevapları veriyor.

Emir: Kanalizasyon sularının arıtılması

Elif: Enerji elde etmek için fosil yakıtların kullanılması

Murat: Plastik malzemelerin etrafa dağılmaması için gömülmesi

Buna göre öğretmenin sorduğu soruya hangi öğrenci ya da öğrenciler doğru cevap vermiştir?
A) Yalnız Elif
B) Emir ve Murat
C) Yalnız Emir
D) Elif ve Murat 
18. 1979'da Romanya'ya ham petrol taşıyan tanker gemisi, bir kuru yük gemisine çarpmış ve büyük bir patlama olmuştur. Bu kazanın sonucunda yangın çıktığı ve çok miktarda petrolün denize karıştığı bilinmektedir.

Bu bilgilere dayanarak kaza sonucu aşağıdakilerden hangisi ya da hangilerinin yaşanmış olduğunu söyleyebilirsiniz?

I. Hava kirliliği gözlenmiştir.

II. Toplu balık ölümleri gözlenmiştir.

III. Biyoçeşitlilikte artış gözlenmiştir.
A) I ve II
B) I ve III
C) II ve III
D) I, II ve III

19. Büşra, Aynur, Yunus ve Berat sosyal medyada biyoçeşitliliği korumak için paylaşımlarda bulunan iki farklı sayfadan hangisini seçeceklerine karar verememişlerdir. Birbirlerini sayfaların biyoçeşitliliği korumak için paylaştıkları önerileri göstererek ikna etmeye çalışmaktadırlar. Daha sonra ikişerli olarak farklı sayfaları takip etmeye karar vermişlerdir. Sizce hangi iki öğrenci doğru paylaşımlar yapan sayfayı seçmişlerdir?
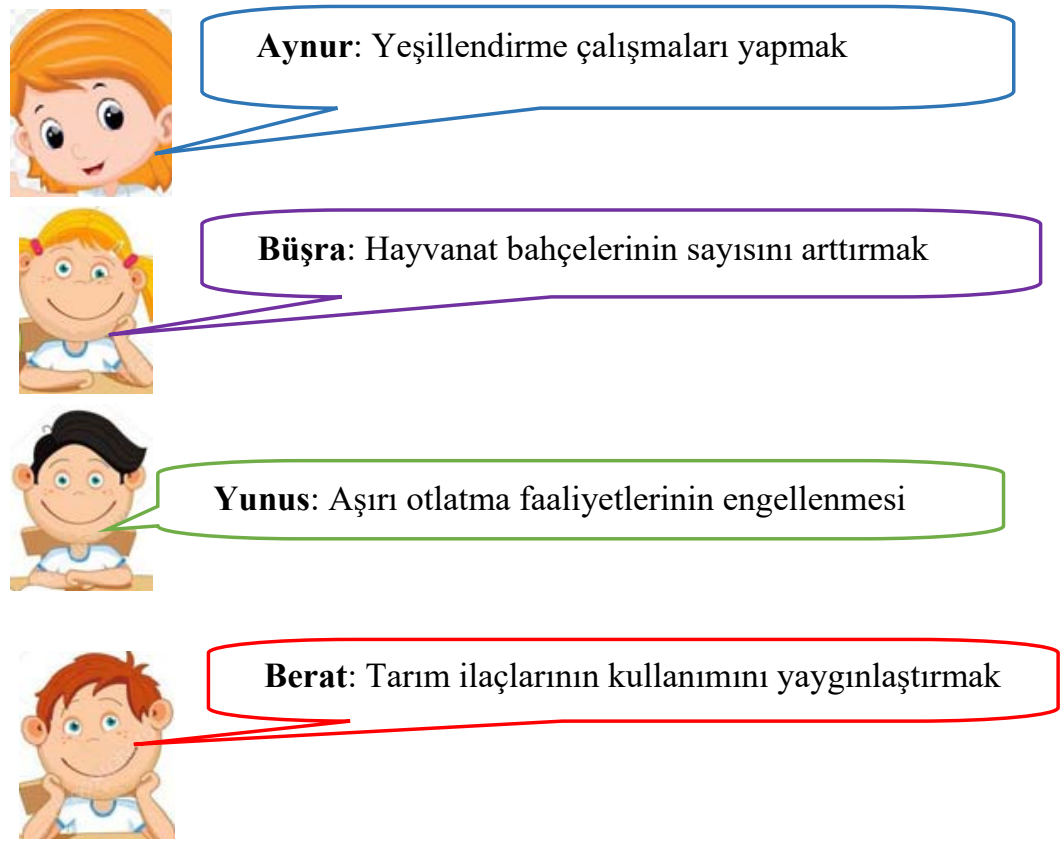
A) Aynur ve Büşra
B) Berat ve Yunus
C) Aynur ve Yunus
D) Berat ve Büşra 
20. Aşağıdakilerden hangisinin çevreye ve insan yaşamına etkisi diğerlerinden çok daha uzun yıllar sürer?

A) Düşük kalorili kalitesiz kömür kullanımından kaynaklanan hava kirliliği

B) Nükleer santral patlaması sonucu açığa çıkan radyasyon

C) Göllerin çevresindeki tarım arazilerinin aşırı gübrelenmesi sonucu gölde yaşayan canlılara verilen zarar

D) Balıkçı gemilerinin çarpışması sonucu denizlerde bulunan enkaz

21.

I. Yerleşim yerleri çevresinde oluştuğunda can ve mal kayıplarına neden olur.

II. Evlerin toprak altında kalmasına neden olur.

III. Topraktan oluşmuş kütlelerin koparak yer değiştirmesi olayıdır.

Yukarıda özellikleri verilen doğa olayı aşağıdakilerden hangisidir?
A) Kasırga
B) $\mathrm{Sel}$
C) Heyelan
D) Deprem

22. Bir televizyon kanalında biyoçeşitliliği tehdit eden faktörler ve alınması gereken önlemler ile ilgili bir program yayınlanmaktadır.

\begin{tabular}{|c|l|l|}
\hline KANALLAR & ÖRNEK DURUM & ÖNERI \\
\hline A & $\begin{array}{l}\text { Akarsu, göl ve denizlerde } \\
\text { biriken kirletici maddeler } \\
\text { balılarla beslenen } \\
\text { hayvanlar yoluyla karaya } \\
\text { geçebilir. }\end{array}$ & Bataklık alanlar kurutulmalıdır. \\
\hline B & $\begin{array}{l}\text { Deniz kaplanı gibi } \\
\text { canlıların nesli } \\
\text { tükenmektedir. }\end{array}$ & $\begin{array}{l}\text { Nesli tükenme tehlikesi ile karşı } \\
\text { karşıya olan hayvanlar resmi izinle } \\
\text { avlanmalıdır. }\end{array}$ \\
\hline $\mathrm{C}$ & $\begin{array}{l}\text { Orkideler salep yapmak } \\
\text { için kullanıldığından nesli } \\
\text { tükenme tehlikesi ile karşı } \\
\text { karşıa kalmaktadır. }\end{array}$ & $\begin{array}{l}\text { Sanayi tesisleri, kültürel değeri olan } \\
\text { arazilere yakın, tarım alanlarına } \\
\text { uzak olmalıdır. }\end{array}$ \\
\hline $\mathrm{D}$ & $\begin{array}{l}\text { Kelaynak, alageyik, ceylan } \\
\text { gibi türler gerekli önlemler } \\
\text { alınmazsa soylarını devam } \\
\text { ettiremeyecektir. }\end{array}$ & $\begin{array}{l}\text { Nesli tükenme tehlikesi altında olan } \\
\text { canlıların yaşam alanlarında sanayi } \\
\text { ve faaliyetleri } \\
\text { sinırlandırılmalıdır. }\end{array}$ \\
\hline
\end{tabular}

Yukarıda verilen televizyon kanallarından hangisinin örnek durum için verdiği öneri doğrudur? 

A) A Kanalı
B) B Kanal1
C) C Kanalı
D) D Kanal1

23. 5 Haziran Dünya Çevre Günü kutlamasında gerçekleştirilen törende konuşma yapan Sedat Öğretmen, "Son yıllarda herkesin farkında olduğu insanlığın geleceğini yakından ilgilendiren çevre sorunlarının çözümü ile ilgili hepimize görev düşmektedir. Çevreye gereken ilgiyi ve duyarlılığı göstermediğimiz takdirde gelecekte bizi pek çok sorun bekliyor olacak.

Örneğin... .."

Sedat Öğretmenin verdiği örnek aşağıdakilerden hangisi olamaz?

A) Sulak alanların kirletilmesi salgın hastalıkların artmasına neden olacaktır.

B) Hayvan tür sayısının hızlı artması ormanların yok olmasına neden olacaktır.

C) Fosil yakıt kullanımının artması sonucu açığa çıkan gazlar küresel ısınmaya neden olacaktır.

D) Aşırı gübreleme yapılan topraktan verimli ürün elde etmek zorlaşacaktır.

\section{GAZETE HABERI}

Şanlıurfa Suruç'a bağlı Dumluköy Ortaokulu öğrencileri, güneş enerjisiyle çalışan araba icat etti. Saatte 25 kilometre hız yapan arac1 geliştiren öğrenciler hedeflerinin doğal kaynaklardan faydalanarak yaşanabilir ortamlar yaratmak olduğunu ifade ettiler.

24. Yukarıdaki gazete haberinde olduğu gibi güneş enerjisinin kullanımı ile ilgili bu gelişmelerin zamanla devam etmesi ve yaygınlaşması sonucu aşağıdakilerden hangisinin olması beklenir?
A) Küresel 1sınmanın hızlanması
B) Havadaki oksijen miktarının azalması
C) Fosil yakıt kullanımının azalması
D) Havadaki karbondioksit miktarının artması

25. Melisa: “ asit yağmurlarının oluşmasına neden olabilir."

I. Melisa'nın bahsettiği çevre kirliliği türü hangisidir?

II. Aşağıdakilerden hangisi Melisa'nın bahsettiği çevre kirliliği türüne karşı alınması gereken önlemlerden biridir?

\begin{tabular}{l|l|l|}
\cline { 2 - 3 } \multicolumn{1}{c|}{} & I. & \multicolumn{1}{|c|}{ II. } \\
\cline { 2 - 3 } A) & Toprak Kirliliği & Elektronik atıklar geri dönüşüm kutusuna atılmalıdır. \\
\cline { 2 - 3 } B) & Hava Kirliliği & Ağaçlandırma ve yeşillendirme çalışmaları yapılmalıdır. \\
\cline { 2 - 3 } C) & Su Kirliliği & Atık suların denizlere, akarsu ve göllere karışması \\
\cline { 2 - 3 } & & önlenmelidir.
\end{tabular}


D)

\begin{tabular}{|l|l}
\hline Hava Kirliliği & Fabrikalar atıklarını akarsulara boşaltmamalıdır. \\
\hline
\end{tabular}

26.

I. Şiddetli rüzgârların sağanak yağmur, kar ve doluyla birlikte çevreyi etkilediği firtınalardır.

II. Dünyanın iç tabakalarında bulunan yüksek sıcaklıkta erimiş haldeki kayaların yer kabuğunun çatlaklarından geçip dışarı çıkmasıdır.

III. Sıcak hava bölgelerinde soğuk hava ile sıcak havanın dar bir alanda aniden yer değiştirmesi ile oluşur.

Yukarıda verilen doğa olayları sırasıyla aşağıdaki seçeneklerden hangisinde verilmiştir?

A)

\begin{tabular}{|l|l|l|}
\hline \multicolumn{1}{|c|}{ I } & \multicolumn{1}{c|}{ II } & \multicolumn{1}{c|}{ III } \\
\hline Hortum & Heyelan & Kasırga \\
\hline Hortum & Yanardağ patlaması & Kasırga \\
\hline Kasırga & Heyelan & Hortum \\
\hline Kasırga & Yanardağ Patlaması & Hortum \\
\hline
\end{tabular}

27. Nesli tükenme tehlikesi altında olan bitkileri korumak için onların yaşam alanlarının da korunması gerekir. Aşağıdakilerden hangisi bu bitkilerden biri değildir?

A) Salep Orkidesi

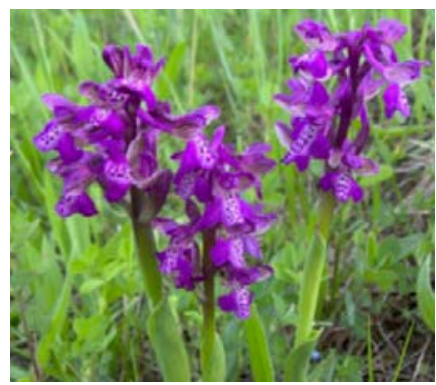

C) Çiğdem

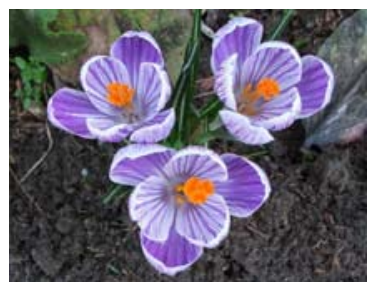

B) Nergis

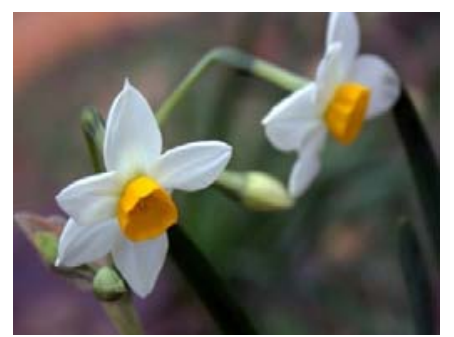

D) Yaban Mersini

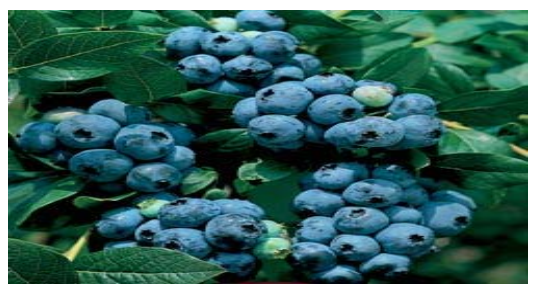

